\title{
The implementation of learning model and virtual lab toward learning outcome of chemistry education
}

\author{
Gulmah Sugiharti ${ }^{1,2,}$, Abdul Hamid ${ }^{3}$ and Mukhtar ${ }^{4}$ \\ 'Educational Technology Study Program, Postgraduate, Universitas Negeri Medan, Medan 2022l, Indonesia \\ ${ }^{2}$ Department of Chemistry, Universitas Negeri Medan, Medan 20221, Indonesia \\ ${ }^{3}$ Department of Building Engineering, Universitas Negeri Medan, Medan 20221, Indonesia \\ ${ }^{4}$ Department of Mathematics, Universitas Negeri Medan, Medan 2022l, Indonesia
}

${ }^{*}$ Corresponding author: (GS), gulmahsugiharti@yahoo.com

DOI: 10.24114/jpkim.v1li3.15734

Received: 25 June 2019; Accepted: 27 November 2019

Abstract:

The abundance of chemical concepts and general chemistry lessons that tend to be monotonous and have not yet considered the ability of mathematical thinking to cause problems in learning that resulted in low student learning outcomes. Even though the concept can be related to students' daily lives by applying effective learning models in accordance with teaching materials. The purpose of this study was to determine whether there were significant differences in learning outcomes between the classes taught with PBL models and the classes taught in the Dl model in the General Chemistry course at the Chemistry Education department of FMIPA Unimed. The population consists of 2 classes, each of which consists of 26 students taught with different learning models. After the data is tested normal and homogeneous by using SPSS, the hypothesis is tested using $t$ test. Based on the results of the hypothesis test, it is known that the value of Sig. $0.065<0.10$. So it was said that there were significant differences in learning outcomes of classes taught with PBL models with classes taught with the DI model in General Chemistry courses. This study concludes that for the General Chemistry subject learning, it is better to use the PBL model than the Dl model.

Keywords: DI model; general chemistry; project-based learning model; virtual lab

\section{Introduction}

Improving human resources in Indonesia, for instance by renewal in the field of education, namely by improving the quality of educators and education personnel by taking advanced study programs that are relevant in domestic and abroad, conducting training and upgrading, implementing Tri Dharma Perguruan Tinggi for lecturers, the existence of lecturer certification, Higher Education Accreditation and so on.

In the conditions of cognitive conflict, students are faced with three choices, namely ( 1 ) retaining their original intuition (the ability to understand something without reasons, rationality, and intellect); (2) revising some of their intuition through assimilation; and (3) changing their views and accommodating new knowledge (Rhedana, 2017).

But the reality on the ground shows that educational achievement in Indonesia is still far below other Asian countries. Based on the United Nations Development Program (UNDP) report, it was seen that the $2013 \mathrm{HDI}$ (Human Development Index) was ranked 121 of 187 countries. Whereas in 2015, it is still around the order of 108 out of 187 countries (UNDP, 2015).

Chemistry studies about the composition, structure, properties, changes in material, and changing energy changes. Chemistry subject can be packaged more simply than it actually is. 
Learning especially chemistry lessons, teachers are required to have adequate ability in carrying out their learning activities and must be able to realize an effective learning environment and are better able to manage their class so that student learning achievement is high.

The 2012 results of the Program for International Student Assessment (PISA) show that the science scores achieved by Indonesian students are also still below the international average score, which is 382 . This achievement ranks Indonesia 64 th out of 65 participating countries (Dalgamo, 2009). According to data from the Ministry of Education and Culture Indonesia the average score of the National Chemistry Examination in 2014/2015 from 67,478 students is 77.90 where 70.00. This shows that there is still a need to increase the value of Chemistry learning in Indonesia.

In Unimed, the subjects which are closely related to the mastery of basic chemical materials are General Chemistry courses. From the profile data of the organizer of the subject education process with General Chemistry shows that the results of the General Chemistry course joint examination for the last 5 years are still low, where in each semester it does not reach $50 \%$ graduation. The learning done so far is still dominated by lecturers and has not considered the learning model. In this study, in addition to the Direct Instructional (DI) model that has been commonly used, Problem Based Learning (PBL) learning models will be used (Nasution et al. 2018; Harahap et al. 2018; Lukman et al. 2019; Sinambela, 2019). The use of the right learning model is one of the important things as a means of teaching and learning activities to convey knowledge to students and improve learning success (Assriyanto, 2014).

General Chemistry Courses are compulsory subjects for new students, Semester 1 and 2 at FMIPA Unimed. This is because this course is a joint subject that must be mastered to be able to achieve a bachelor's degree at FMIPA Unimed. During this time, learning activities are still dominated by lecturers by requiring students to work on tasks and solve chemical concept questions. Even though the concept can be related to students' daily lives by applying effective learning models in accordance with teaching materials. The use of the right learning model is one of the important things as a means of teaching and learning activities to convey knowledge to and improve learning success (Assriyanto, 2014)

Chemistry studies about the composition, structure, properties, changes in material, and changing energy changes. Chemistry subject can be packaged more simply than it actually is. Learning especially chemistry lessons, teachers are required to have adequate ability in carrying out their learning activities and must be able to realize an effective learning environment and are better able to manage their class so that student learning achievement is high. Chemistry was born from the desire of chemists to get answers to what and why the nature of matter exists in nature, each of its will produce facts and theoretical knowledge about matter whose truth can be explained by mathematical logic. Some aspects of chemistry are visible which means that concrete facts can be made and some aspects are only abstract (invisible) meaning they are not proven by mathematical logic so that rationality can be formulated. Chemistry is defined as a science that studies the structure, composition, nature, and changes in material and energy that accompany these material changes (Silaban, 2017).

Chemistry as a process can mean all scientific activities to perfect knowledge and to find new knowledge. The chemistry learning process emphasizes giving direct experience to develop competencies so that students are able to explore and understand the natural environment in a scientific manner. Obtaining experience in applying the scientific method through experiments or experiments, where students test hypotheses by designing experiments through instrument installation, retrieval, processing and interpretation of data, and delivering experimental results orally and in writing, is a scientific process that must be carried out to obtain knowledge new ones for students. Limitations of tools and materials in chemical learning can be overcome by using a Virtual lab. 
The learning process is an interaction of learning between teachers and students. While the problem in essence is a question that contains answers. So that problem-based learning is an interaction activity between the teacher and students by using questions that contain answers (Asra, 2013). Problem-based learning, later abbreviated PBL, is a learning model that involves students to solve a problem through the stages of the scientific method so that students can learn knowledge related to the problem and at the same time have the skills to solve problems (Ngalimun, 2014). Kivela (2005) describes a problem-based learning model as a learning model that can encourage students to learn independently and improve thinking skills. In short, it can be said that learning starts from one problem and solving problems is the goal of each lesson. PBL does not have a rigid lesson plan and students determine spectacular path for their learning objectives. Thus, PBL allows students to investigate deeply (Kizkapan, 2017). In PBL students' creativity will be solved to solve problems and produce products from existing problems. While in the PBL learning model students' creativity is emphasized to find solving problems that exist in everyday life (Widyasari, 2018).

In PBL there is working group and discussion that requires students to interact with their friends so that new knowledge and skills arise. This knowledge is built through the process of asking questions, group work, discussion and debate when presenting their work, which requires thinking skills, which students can learn communicatively and effectively. In connection with this, Asra (2013) writes that problem solving ability requires a thought process. If the problem can be solved, the student learns something new. Therefore the ability of students to think needs to be improved. .

Direct Interaction teaching model later abbreviated as $\mathrm{Dl}$ is a teaching model that is teacher center. Direct teaching model is one of the teaching approaches specifically designed to support student learning processes that are related to well-structured declarative knowledge and procedural knowledge that can be taught with a step-by-step, gradual activity pattern. In addition, direct learning models are also intended to help students learn basic skills and obtain information that can be taught step by step. Joyce and Weil (2011) wrote that the direct learning model begins with the teacher's explanation of new concepts or skills to students.

The demands of today's educational world have been enjoyable to learn and make it easier for learners to learn. With plan and design that meets the rules and instructional components, the computer can be used as one of the media that can learn individually. Computers will greatly help educators to convey the knowledge to learn and conversely with computer learners will be able to learn easily and surprisingly (Sugiharti, 2018). David (2009) explained that direct learning is learning that is designed to teach knowledge and basic skills that students need for subsequent learning. Direct learning is very useful especially when there are skills that can be mapped into specific steps. Direct learning steps emphasize the role of educators and activate the role of students to build concepts in students. In this case learning should use a variety of appropriate media, such as films, pictures, demonstrations, as well as virtual labs. Laboratories are an important part of teaching science and achieving its objectives. They can be described as controlled conditions in which scientific experiments are carried out (Ambusaidi, 2018).

Virtual lab is a form of learning media by using a laboratory to make observations or experiments through software run by a computer, where all the equipment needed by a laboratory is contained in the software (Eko, 2014). Virtual Laboratories (VLs) are mediums that fulfill those indicated needs (Tatli, 2010). Laboratory virtual is a form of animation that can visualize abstract phenomena or complicated experiments carried out at real laboratory, so it can increase learning activities in an effort develop skills that are Required in problem solving. The virtual laboratory is one the form of computer animation, consists moving image which is represent the state in a real laboratory (Sugiharti, 2017). Virtual Laboratory (VL/Virtual lab) is a set of laboratory tools in the 
form of interactive multimedia based computer software that operates with computer hardware and can simulate activity in the laboratory as if the user is in the actual laboratory (Yuniarti, 2017). There are two main concepts of computer laboratories (Tyder, 2008), namely real estate computer replacements so that experiments take place in the form of virtual animation or experimentation, and laboratory experiments are described as virtual when experiments are not controlled by direct manipulation of laboratory equipment but with computer equipment. The main goal with this virtual lab was to provide a web support to the traditional lab experiment, thus improving student's effectiveness and autonomy in the laboratory class, in data analysis and report writing. Even though this virtual lab is not designed to replace the hands-on experiment, it is reduced by decreasing the time needed to conduct the experiment, decreasing the number of repetitions (due to errors), and also eliminating the need for full-time supervision (Domingues, 2010).

In teaching science teachers often proceed from the fact that nature is the best source of information. The basic and at the same time the most effective method in gaining chemistry related knowledge is experimental and laboratory work. Basic science concepts are introduced by experiments. In school laboratory experiments can be carried out in a realistic or virtual manner. With virtual experiments the experiments are carried out using computer simulations or animations. One of the advantages of virtual laboratory, among other things, is that it allows the portrayal of matter's model structure which is a prerequisite for proper understanding of the natural partition structure of matter (Herga, 2012).

Virtual laboratories provide many benefits that are very useful as a medium to teach safe and cheap, effective to teach abstract concepts that are difficult to understand to overcome the lack of facilities, tools and materials in the laboratory, the expensive tools and chemicals can be overcome with the help of computers. With virtual labs students can see and interact with their own experiments. The virtual lab allows students to conduct chemical experiments as facing real laboratory equipment. So the expected goal of chemistry learning is that the scientific process will be cheaper and cheaper (Sugiharti, 2018).

VCLs depend on virtualization technologies. A virtual computer is an emulation of an operating system and behaves exactly like a real computer. Using this technology, a single computer may host multiple virtual computers with different operating systems which are isolated from one another and share the resources of the host computer. On virtual computers, students can practice advanced skills and perform complex tasks which are not usually allowed on campus computers and networks (Konak, 2014).

\section{Methods}

This research was carried out in 2018 at the Chemistry Education Study Program at FMIPA Unimed. The population in this study were all students of chemistry education study programs who were taking course of General Chemistry which amounts to 4 classes. The class sample was determined as much as 2 classes from 4 classes that were available in the Chemistry Education study program by random sampling. While the research sample consisted of 26 students in each class.

Data Analysis Technique uses descriptive analysis to describe the data, including: average value (mean), median, standard deviation (SD) and data tendency using the SPSS program.

Analysis requirements test used in the form of normality test (NPar Tests), with One-Sample Kolmogorov-Sminov Test and homogeneity test using the Oneway Test of Homogeneity of Variances. While to see whether there is a difference in student learning outcomes, the $t$ test is used. Testing criteria are: Reject $\mathrm{Ho}$, if $\mathrm{t}$ counts $>\mathrm{t} \mathrm{tab}$ 


\section{Results}

Research results such as student learning outcomes data and other requirements are shown in Table 1 and Table 2.

\section{Table 1}

Student learning outcomes data

\begin{tabular}{|c|c|c|}
\hline No & $\mathrm{Al}$ & $\mathrm{A} 2$ \\
\hline 1 & 90 & 80 \\
\hline 2 & 87.5 & 77.5 \\
\hline 3 & 85 & 77.5 \\
\hline 4 & 82.5 & 75 \\
\hline 5 & 82.5 & 75 \\
\hline 6 & 80 & 72.5 \\
\hline 7 & 80 & 72.5 \\
\hline 8 & 77.5 & 72.5 \\
\hline 9 & 77.5 & 70 \\
\hline 10 & 75 & 67.5 \\
\hline 11 & 75 & 65 \\
\hline 12 & 72.5 & 65 \\
\hline 13 & 70 & 62.5 \\
\hline 14 & 80 & 80 \\
\hline 15 & 77.5 & 80 \\
\hline 16 & 77.5 & 77.5 \\
\hline 17 & 75 & 75 \\
\hline 18 & 72.5 & 75 \\
\hline 19 & 70 & 72.5 \\
\hline 20 & 72.5 & 72.5 \\
\hline 21 & 70 & 70 \\
\hline 22 & 70 & 70 \\
\hline 23 & 67.5 & 67.5 \\
\hline 24 & 65 & 67.5 \\
\hline 25 & 62.5 & 65 \\
\hline 26 & 60 & 62.5 \\
\hline SUM & 1955 & 1867.5 \\
\hline MEAN & 75.2 & 71.8 \\
\hline
\end{tabular}

Note :

$A l=$ Group of student taught by PBL model

$A 2$ = Group of student taught by Dl model

\section{Table 2}

Normality Test N Par Test

\begin{tabular}{llrr}
\hline \multicolumn{4}{c}{ One-Sample Kolmogorov-Smirnov Test } \\
\hline $\mathrm{N}$ & $\mathrm{Al}$ & $\mathrm{A} 2$ \\
\hline Normal Parameters & & \\
& & 26 & 26 \\
Most Extreme Differences & Mean & 75.1923 & 71.8269 \\
& Std. Deviation & 7.34585 & 5.36459 \\
& Absolute & .086 & .127 \\
& Positive & .069 & .098 \\
Test Statistic & Negative & -.086 & -.127 \\
Asymp. Sig. (2-tailed) & .086 & .127 \\
\hline a. Test distribution is Normal. & $.200^{\mathbf{c , d}}$ & $.200^{\mathrm{c}, \mathrm{d}}$ \\
b. Calculated from data. & & \\
c. Lilliefors Significance Correction. & & \\
d. This is a lower bound of the true significance. & &
\end{tabular}


Based on result of Normality test Kolmogorov Smirnov, known that value of Sig. Class Al and A2 > 005. Therefore if Sig > 0.05, data is normally distributed, so can be concluded that distribution of postest outcome Class $A 1$ and $A 2$ are normal.

\section{Homogenity test}

Table 3

Test of homogeneity of variances

\begin{tabular}{cccc}
\hline \multicolumn{4}{c}{ Model } \\
\hline Levene Statistic & $\mathrm{dfl}$ & $\mathrm{df2}$ & Sig. \\
\hline 1.730 & 1 & 50 & 194 \\
\hline
\end{tabular}

Table 4

ANOVA

\begin{tabular}{lrcrrr}
\hline Model & & & & & \\
\hline & Sum of Squares & df & Mean Square & F & Sig. \\
\hline Between Groups & 147.236 & 1 & 147.236 & 3.559 & 065 \\
Within Groups & 2068.510 & 50 & 41.370 & & \\
Total & 2215.745 & 51 & & & \\
\hline
\end{tabular}

Based on result of Normality test Kolmogorov Smirnov, known that value of Sig. Class $\mathrm{Al}$ and A2 > 005. Therefore if Sig > 0.05, data is normally distributed, so can be concluded that distribution of postest outcome Class $\mathrm{A} 1$ and $\mathrm{A} 2$ are normal.

Table 5

Hypotesis Test of T-Test

\begin{tabular}{lcrrrr}
\hline \multicolumn{6}{c}{ Group Statistics } \\
\hline Model & Kelas & Mean & Std. Deviation & Std. Error Mean \\
& Kelas PBL & 26 & 75.1923 & 7.34585 & 1.44064 \\
& Kelas DI & 26 & 71.8269 & 5.36459 & 1.05208 \\
\hline
\end{tabular}

\section{Discussion}

Hypothesis test obtained Fcount (A) and (B) equal to $18,551>$ Ftabel $(0,05)(1,48)=4,04$ hence there is significant interaction between learning model using virtul lab and learn to result of chemistry learning students on General Chemistry. There are various studies that link between the use of Virtual lab and Real labs such as research conducted by Tatli and Ayas (2013), which describes that "Virtual chemistry labs are slightly more effective than Real labs, both of which show the achievement and ability of students to recognize laboratory equipment". Another study was conducted by Hutabarat et al. (2017) which states that there is an influence of the PBL learning model using Real media labs and Virtual labs. From mean of cognitive learning achievement of students using learning PBL Virtual laboratories (71.25\%) better than student using PBL learning with Real lab (58.75\%). In addition, this study was also supported by Kusnadi et al. (2013) which showed a difference in the learning outcomes of chemistry by using a virtual laboratory (73.9\%) slightly higher than that of Real lab (70.8\%). Sugiharti and Hasibuan (2017) show that there is influence of learning model by using real laboratory and virtual laboratory on students' chemical learning result on reaction rate material with $F$ count $>F$ table i.e. 28.6367 $>3.99$, and Savery (2006) wrote that the PBL models is a student-centered learning that empowers students to apply knowledge and skills to develop the best solution or problem solving. 


\section{Conclusion}

This research conclude that study the course of General Chemistry is better to use learning model of PBL than learning model $\mathrm{DI}$, where the outcomes of study the student using PBL model higher than DI model.

\section{Acknowledgments}

Acknowledgments to DRPM DIKTI for the support of the doctor's dissertation research (PDD) and the Unimed Leader who has given me permission to study permit.

\section{References}

Ambusaidi, A., Al Musawi, A., \& Al-Balushi, S. (2018). The impact of virtual lab learning experiences on 9th grade students' achievement and their attitudes towards science and learning by virtual lab. Journal of Turkish Science Education, 15, 13-29, doi: 10.12973/tused.10227a.

Asra, S. (2013). Metode Pembelajaran. CV Wacana Prima, Bandung.

Assriyanto, K.E., Sukardjo, J.S., \& Sulistyo, S. (2014). Pengaruh model pembelajaran berbasis masalah melalui metode eksperimen dan inkuiri terbimbing ditinjau dari kreativitas siswa pada materi larutan penyangga. Jurnal Pendidikan Kimia (JPK), 3, 90-91.

Dalgamo, B., Bishop, A.G., \& Bedgood, D.R. (2009). Develoving and interactive virtual chemistry laboratory enriched with contructivist learning activities for secondary schools. journal of chemical education, 82, 853-865.

David, A., Jacubsens., \& Paul, E. (2009). Methode for teaching. Pustaka Pelajar, Yogyakarta.

Domingues, L., Rocha, 1., Dourado, F., Alves, M., \& Eugénio, C.F. (2010). Virtual laboratories in (bio)chemical engineering education. Journal education for chemical engineers, 5, 22-27, doi: 10.1016/j.ece.2010.02.001.

Eko, S., \& Leny, Y. (2014). Penerapan media laboratorium virtual (PhET) pada materi laju reaksi dengan model pengajaran langsung. Jurnal Pendidikan Kimia UNESA, 13, 119-133.

Harahap, N.M., Hutabarat, W., \& Silaban, S. (2018). The effect of model problem based learning (pbl) assistance of prezi media on student learning outcomes in colloid materials. Advances in Social Science, Education and Humanities Research, 200,456-458, doi: 10.2991/aisteel-18.2018.98

Herga, N.R., \& Dinevski, D. (2012). Virtual laboratory in chemistry-experimental study of understanding, reproduction and application of acquired knowledge of subject's chemical content. Jurnal Organizacija, 45(3), 108-116, doi: 10.2478/v10051-012-0011-7.

Hutabarat, W., Sinaga, M., \& Silaban, S. (2017). Implementasi model problem based learning dalam perkuliahan daspen mipaprodi pendidikan kimia. Prosiding Seminar Hilirisasi Penelitian untuk Kesejahteraan Masyarakat, 384-388.

Joyce, B., \& Weill, M. (2011). Models of Teaching. Model-model pengajaran. Pustaka Pelajar Yogjakarta.

Kizkapan, O. (2017). The Effect of Project Based Learning on Seventh Grade Students' Academic Achievement. Journal of Instruction, 10, 37-54, doi: 10.12973/iji.2017.1013a.

Kivela. (2005). Student Perceptions of an embedded problem-based learning instructional approach in a hospitality undergraduate program, International Journal of Hospitality Management, 24, 437-464.

Konak, A., Tricia, K., \& Clark, M. (2014). Using Kolb's Experiential Learning Cycle to improve student learning in virtual computer laboratories. Journal Computers \& Education, 72, 11-22, doi: 10.1016/j.compedu.2013.10.013.

Kusnadi. (2013), Pembelajaran kimia dengan problem based learning menggunakan laboratorium real dan virtual ditinjau dari kemampuan matematika dan kemampuan berpikir abstrak siswa. Jurnal Inkuiri, 2(2), 163-172.

Lukman, l., Damanik, M., Silaban, S., \& Kembaren, A. (2019). Development of problem based learning innovative student worksheets in learning the concept of chemistry for senior high school students. Journal of Transformative Education and Educational Leadership, 1(1), 23-28.

Nasution, R., Silaban, S., \& Sudrajat, A. (2018). The influence of problem based learning, guided inquiry learning models assited by lectora inspire, and scientific attitudes to student's cognitive values. 
Advances in Social Science, Education and Humanities Research, 200, 265-269, doi: 10.2991/aisteel18.2018 .58

Ngalimun, S. (2014). Strategi dan Model Pembelajaran. Aswaja Pressindo, Jakarta.

Redhana, l., W. Sudria, I.B.N., Hidayat, l., \& Merta, L.M. (2017). Identification of chemistry learning problems viewed from conceptual change model. Journal of Chemical Education, 6(2), 356-364, doi: 10.15294/jpii. v6il.9594.

Savery, J. R. (2006). Overview of Problem-based learning: Definitions and distinctions, the interdisciplinary. Journal of Problem-Based Learning, 1(1), doi: 10.7771/1541-5015.1002

Silaban, S. (2017). Dasar-dasar pendidikan matematika dan ilmu pengetahuan alam. Medan: Harapan Cerdas Publisher.

Sinambela, P. N. J. M. (2019). Development of Mathematical Learning Model to Improve Students' Reasoning and Problem Solving Competencies. Journal of Transformative Education and Educational Leadership, 1(1), 9-12.

Sugiharti, G., \& Hasibuan, S. K. (2017). The effect of inquiry learning method by using laboratory and logical thinking on learning outcome in chemical reaction Rate Jurnal Pendidikan Kimia (JPKim), 9(1), 229-235, doi: 10.24114/jpkim.v9i1.6184.

Sugiharti, G. (2018). Improve outcomes study subjects chemistry teaching and learning strategies through independent study with the help of computer-based media. Journal of Pyhsics, 970, 1-5, doi: 10.1088/1742-6596/970/1/012018.

Sugiharti, G., \& Eva, R.L. (2018). Application of learning model with virtual lab and motivation in learning chemistry. Jurnal Pendidikan Kimia, 10, 362-365, doi: 10.24114/jpkim.v10i1.9676.

Tyder, J. (2008). An online virtual laboratory of electricity International. Journal of Distance Education Technologies. 6, 21-23.

Tatli, Z., \& Ayas, A. (2010). Virtual laboratory applications in chemistry education. Procedia Social and Behavioral Sciences, 9, 938-942, doi: 10.1016/j.sbspro.2010.12.26.

UNDP, Human Development Index and its component Tabel 1 ( diakses tanggal 15 Februari 2016).

Widyasari, F., Indriyati, N.Y., \& Mulyani, S. (2018). Pengaruh pembelajaran kimia dengan model pjbl dan pbl berdasarkan representasi tetrahedral kimia ditinjau dari kreativitas siswa. Jurnal Kimia dan Pendidikan Kimia, 3(2), 93-102, doi: 10.20961/jkpk.v3i2. 16638.

Yuniarti, A., Yeni, L.F., \& Yokhebed. (2017). Development of virtual laboratory based on interactive multimedia on planting and painting bacteria. J. Phys.: Conf. Ser, 895 012120, doi: 10.1088/17426596/895/1/012120. 